\begin{tabular}{|c|l|}
\hline Title & $\begin{array}{l}\text { Significant and prolonged antisense effect of a multifunctional envelope ty pe nano device encapsulating antisense } \\
\text { oligodeoxynucleotide }\end{array}$ \\
\hline Author(s) & Nakamura, Y oshio; Kogure, Kentaro; Y amada, Y uma; Futaki, Shiroh; Harashima, Hidey oshi \\
\hline Citation & $\begin{array}{l}\text { Journal of Pharmacy and Pharmacology, 58(4), 431-437 } \\
\text { https://doi.org/10.1211/pp.58.4.0002 }\end{array}$ \\
\hline Issue Date & 2006-04 \\
\hline Doc URL & http://hdl.handle.net/2115/13686 \\
\hline Type & article \\
\hline File Information & JPP03.pdf \\
\hline
\end{tabular}

Instructions for use 
JPP 2006, 58: 431-437

(c) 2006 The Authors

Received August 9, 2005

Accepted December 20, 2005

DOI 10.1211/jpp.58.4.0002

ISSN 0022-3573
Graduate School of

Pharmaceutical Sciences, Hokkaido University, Kita-12,

Nishi-6, Kita-ku,

Sapporo 060-0812, Japan

Yoshio Nakamura, Kentaro

Kogure, Yuma Yamada,

Hideyoshi Harashima

CREST Japan Science and Technology Agency (JST), Japan

Kentaro Kogure,

Hideyoshi Harashima

PRESTO Japan Science and Technology Agency (JST), Japan

Shiroh Futaki

Institute for Chemical Research, Kyoto University, Uji, Kyoto 611-0011, Japan

Shiroh Futaki

Correspondence: $\mathrm{K}$. Kogure Graduate School of Pharmaceutical Sciences, Hokkaido University, Kita 12, Nishi 6, Kita-ku, Sapporo 060-0812, Japan. E-mail: kogure@pharm.hokudai.ac.jp

Funding: This work was supported, in part, by Grants-in-Aid for Scientific Research (B) from the Ministry of Education, Culture, Sports, Science and Technology of Japan, and by Grants-in-Aid for Scientific Research on Priority Areas from the Japan Society for the Promotion of Science.
Research Papers

\section{Significant and prolonged antisense effect of a multifunctional envelope-type nano device encapsulating antisense oligodeoxynucleotide}

\author{
Yoshio Nakamura, Kentaro Kogure, Yuma Yamada, Shiroh Futaki and \\ Hideyoshi Harashima
}

\begin{abstract}
A multifunctional envelope-type nano device (MEND) was developed for use as an efficient non-viral system for the delivery of plasmid DNA (pDNA) using octaarginine (R8) as an internalizing ligand. Three types of R8-MENDs were prepared, co-encapsulating luciferase-encoding pDNA and antiluciferase oligodeoxynucleotide (ODN) condensed by three polycations, stearyl octaarginine (STRR8), poly-L-lysine (PLL) and protamine, and the antisense effects of the ODN-encapsulated R8-MENDs (ODN-MEND) were analysed in-vitro. The ODN-MEND packaged using protamine as a condenser showed a $90 \%$ antisense effect $16 \mathrm{~h}$ after the transfection, and a persistent antisense effect of over $75 \%$ for up to $48 \mathrm{~h}$, which was much more effective than that of LipofectAmine2000. On the other hand, the ODN-MENDs prepared using PLL and STR-R8 as condensers did not show any significant inhibition of luciferase activity. Although there was no specific relation between the physicochemical characteristics of the ODN-MENDs and their antisense effect, the pattern of the antisense effect among the ODN-MENDs was similar to that of the silencing effect of R8-MEND encapsulating plasmid DNA encoding siRNA. These results suggest that R8-MENDs are able to deliver encapsulated DNA to the cytosol as well as to the nucleus, and that protamine can also function as an efficient decondenser, not only in the nucleus but also in the cytosol. In conclusion, we successfully developed an ODN-MEND with a high antisense effect using protamine as a DNA condensing as well as a decondensing agent.
\end{abstract}

\section{Introduction}

In the field of gene silencing research, the use of antisense oligodeoxynucleotides (ODNs) has various advantages, such as their ability to target introns and modification for the improvement of selectivity and efficacy (Scherer \& Rossi 2003). Zamecnik \& Stephenson first demonstrated that a 13-mer ODN complementary to terminally repeated sequences in the long terminal repeat of the Rous sarcoma virus (RSV) inhibited RSV translation in a cell-free system and viral replication in cultured cells (Stephenson \& Zamecnik 1978; Zamecnik \& Stephenson 1978). Since then, attempts have been made to use ODN-based approaches therapeutically in treating serious diseases, such as cancer (Miyake et al 2001) and hypertension (Phillips 2001). However, there are some problems associated with this approach, such as degradation by nucleases and difficulties associated with targeting and intracellular delivery (Shi \& Hoekstra 2004). Thus, an efficient method of packaging ODNs is needed to solve these problems.

Several packaging methods for an ODN have already been reported. Gokhale et al (1997) encapsulated ODN with a lipid membrane by rehydrating a dried lipid film in the presence of ODN. Shi \& Hoekstra (2004) reported on the encapsulation of an ODN with a cationic lipid by a freeze-thaw method. In addition, Semple et al (2001) constructed stabilized antisense-lipid particles (SALP) by packaging an ODN with a $\mathrm{pH}$-sensitive cationic lipid. These methods were based on electrostatic interactions 
between the anionic ODN and the cationic lipids. Each method, however, required a lengthy procedure and the encapsulation efficiency was low.

We developed a multifunctional envelope-type nano device (MEND) as a novel delivery system of plasmid DNA (pDNA) (Kogure et al 2004). MEND is a liposomaltype non-viral delivery system that mimics an envelopetype virus, and is composed of a positively charged condensed DNA core covered with a negatively charged lipid membrane based on electrostatic interactions. Furthermore, the MEND can be equipped with various functional devices, such as a $\mathrm{pH}$-sensitive fusogenic peptide for membrane fusion (Yamada et al 2005a), a ligand for specific targeting (Kakudo et al 2004), a cell-penetrating peptide for efficient cellular uptake and polyethylenglycol for stabilization in the circulating blood by controlling the topology of the envelope membrane (Sasaki et al 2005). Using this system, the transfection activity of the MEND was enhanced by two orders of magnitude by introducing stearyl octaarginine (STR-R8), a wellknown and efficient cell-penetrating peptide (Futaki et al 2001; Nakase et al 2004), on the envelope (Kogure et al 2004).

We recently also developed a novel packaging method for an ODN to a MEND (Yamada et al 2005b). The encapsulation efficiency and preparation time for this method were significantly better than those of the SALP method and the freeze-thaw method. In this study, we report on the construction of three types of octaargininemodified MEND (R8-MEND) encapsulating ODN condensed by three polycations (STR-R8, poly-L-lysine (PLL) and protamine) and then compared the antisense effects of the ODN-encapsulated R8-MENDs.

\section{Material and Methods}

\section{Materials}

1,2-Dioleoyl-sn-glycero-3-phosphoethanolamine (DOPE) was purchased from AVANTI Polar Lipids Inc. (Alabaster, AL, USA). Cholesteryl hemisuccinate (5-cholesten-3-ol 3hemisuccinate; CHEMS) and poly-L-lysine (PLL; MW 27 400) were obtained from Sigma-Aldrich Co. (St Louis, MO, USA). Stearyl octaarginine (STR-R8) was synthesized as described previously (Futaki et al 2001). Protamine sulfate was purchased from Merck KGaA (Darmstadt, Germany). LipofectAmine 2000 was obtained from Invitrogen Co. (Carlsbad, CA, USA). The pDNA pCMV-luc (7037 bp) encoding luciferase was prepared by EndFree Plasmid Mega Kit (Qiagen GmbH, Hilden, Germany). The anti-luciferase antisense ODN (19mer, 5'-AACCGCTTCCCC GACTTCC-3') used a sequence reported (Xu et al 2003), and was obtained from Sigma-Aldrich Japan K.K. (Tokyo, Japan). NIH3T3 cells were obtained from the American Type Culture Collection (Manassas, VA, USA).

\section{Preparation of R8-MEND}

The procedure for the preparation of R8-MEND comprised four steps as follows (schematically shown in Figure 1) (Kogure et al 2004).

Firstly, for DNA (ODN or pDNA) condensation with a polycation (PLL, STR-R8, and protamine), DNA and the polycation were dissolved with $10 \mathrm{~mm}$ HEPES buffer ( $\mathrm{pH}$ 7.4). To condense the DNA, the DNA solution $\left(0.1 \mathrm{mg} \mathrm{mL}^{-1}\right)$ was added to the polycation solution $\left(0.1 \mathrm{mg} \mathrm{mL}^{-1}\right)$ under vortexing at room temperature. In

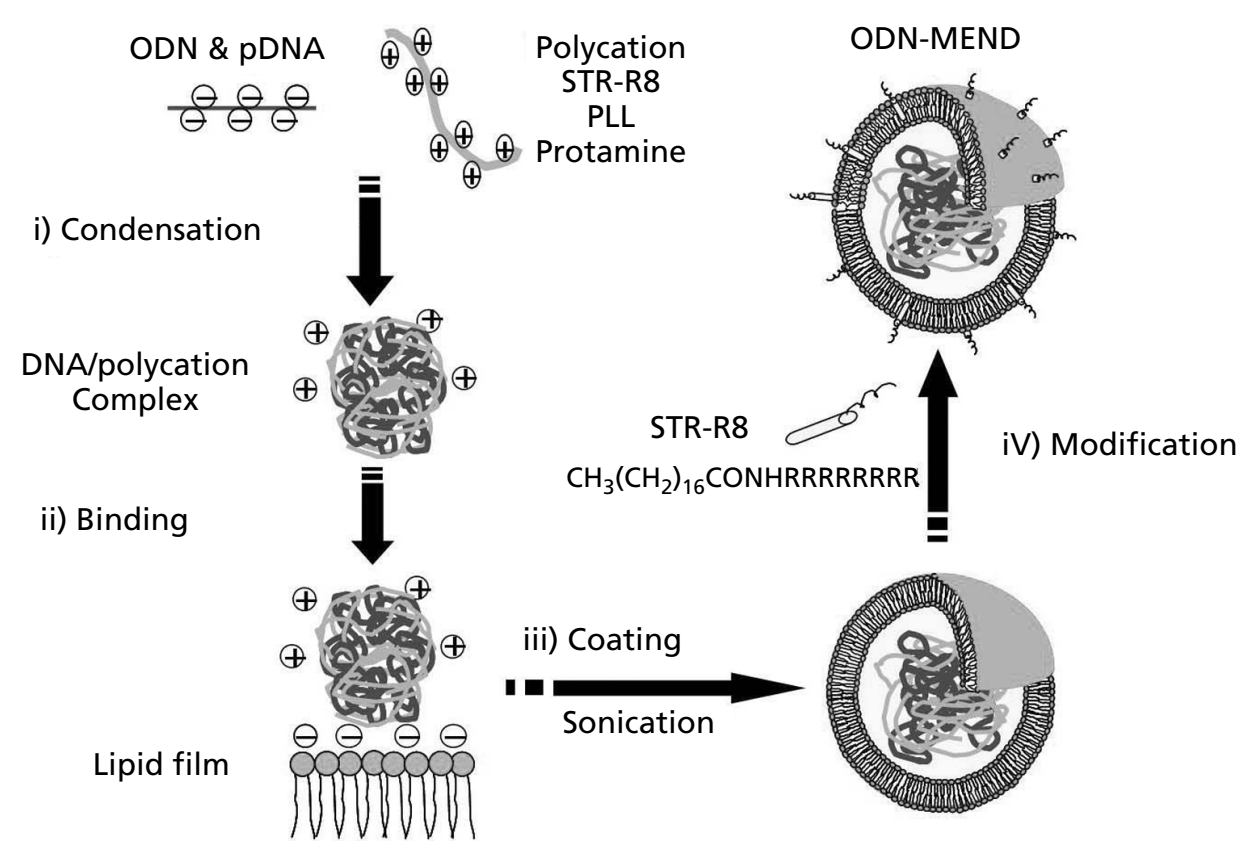

Figure 1 Scheme for the packaging of the ODN-MEND. The packaging comprised 4 steps: i, condensation of ODN; ii, binding of condensed-ODN to lipid film; iii, lipid coating by sonication; iv, modification of the lipid membrane by STR-R8. 
the case of co-packaging of ODN and pDNA to the MEND, the weight ratio of ODN to pDNA was $1: 1$ $(748: 1 \mathrm{~mol} / \mathrm{mol})$. The DNA content of a suspension of the DNA/STR-R8 complex prepared at a nitrogen/phosphate $(\mathrm{N} / \mathrm{P})$ ratio of 2.9 was $0.033 \mathrm{mg} \mathrm{mL}^{-1}$. The DNA content of a suspension of the DNA/PLL complex prepared at a nitrogen/phosphate $(\mathrm{N} / \mathrm{P})$ ratio of 2.4 was $0.05 \mathrm{mg} \mathrm{mL}^{-1}$. The DNA content of suspension of DNA/protamine complex prepared at a nitrogen/phosphate $(\mathrm{N} / \mathrm{P})$ ratio of 2.2 was $0.04 \mathrm{mg} \mathrm{mL}^{-1}$.

Secondly, electrostatic binding of condensed DNA to lipid film was carried out. After the condensation of DNA, $0.25 \mathrm{~mL}$ of the DNA/polycation complex (DPC) suspension was added to the lipid film, formed by the evaporation of a chloroform solution of $137.5 \mathrm{nmol}$ lipids (DOPE/CHEMS = 9:2 (molar ratio)) on the bottom of a glass tube, followed by incubation for $10 \mathrm{~min}$ to hydrate the lipids. The final concentration of lipid was $0.55 \mathrm{~mm}$.

Thirdly, the condensed DNA was coated with lipid. To coat the DPC with lipids, the glass tube was sonicated for about $1 \mathrm{~min}$ in a bath-type sonicator $(125 \mathrm{~W}$, Branson Ultrasonics, Danbury, CT, USA).

Finally, modification of the lipid envelope with $\mathrm{R} 8$ peptide was carried out. An STR-R8 solution $(5 \mathrm{~mol} \%$ of lipids) was added to the suspension to attach the membrane-permeable peptide $\mathrm{R} 8$ to the envelope of the lipidcoated particle, and the mixture was then incubated for $30 \mathrm{~min}$ at room temperature.

The hydrodynamic diameter was measured by a quasielastic light-scattering method and the zeta-potential was determined electrophoretically by means of an electrophoretic light-scattering spectrophotometer (ELS-8000, Otsuka Electronics, Japan).

\section{Sucrose density gradient fractionation}

R8-MEND containing FITC-labelled ODN (15\% of total ODN) and rhodamine-labelled DOPE ( $1 \mathrm{~mol} \%$ of total lipids) was layered on a discontinuous sucrose density gradient $(0-60 \%)$, and centrifuged at $160000 \mathrm{~g}$ for $2 \mathrm{~h}$ at $20^{\circ} \mathrm{C}$. A 1-mL sample was collected from the top and the fluorescence intensities of FITC and rhodamine were measured. Furthermore, to estimate fluorescence resonance energy transfer (FRET) between FITC and rhodamine, each fraction sample was solubilized in $1 \%$ sodium dodecyl sulfate (SDS), and the fluorescence intensities were then measured. The trapped amount of ODN was obtained by the sum of fluorescent intensities of FITC in the fractions, which showed FRET. The encapsulation efficiency was calculated by the amount of ODN in the ODN-encapsulated fractions divided by the total amount of ODN multiplied by 100 .

\section{Co-transfection assay}

The MEND containing $0.04 \mu \mathrm{g}$ DNA (pDNA:ODN $=1: 748$, mol:mol) or lipoplex (pDNA:ODN $=1: 748, \mathrm{~mol}: \mathrm{mol})$ containing $0.04 \mu \mathrm{g}$ with LipofectAmine2000 were suspended in $0.25 \mathrm{~mL}$ of DMEM without serum and added to $4 \times 10^{4}$ NIH3T3 cells followed by incubation for $3 \mathrm{~h}$ at $37^{\circ} \mathrm{C}$. Next, $1 \mathrm{~mL}$ of DMEM containing $10 \%$ fetal calf serum was added to the cells, followed by a further incubation for $5,13,21$ or $45 \mathrm{~h}$. The cells were then washed, and solubilized with reporter lysis buffer (Promega, Madison, WI). Luciferase activity was initiated by the addition of $100 \mu \mathrm{L}$ of luciferase assay reagent (Promega) to $20 \mu \mathrm{L}$ of cell lysate, and measured by means of a luminometer (Luminescencer-PSN; ATTO, Japan). The amount of protein in the cell lysate was determined using a BCA protein assay kit (PIERCE, Rockford, IL, USA). The control luciferase activity was determined using control MEND encapsulating luciferase $\mathrm{pDNA}$ and anti-green fluorescent protein (GFP) ODN as non-related control ODN. The percentage of antisense effect was calculated by subtracting the luciferase activity of the ODN-encapsulated R8-MEND (antisense) from the control luciferase activity divided by the control luciferase activity multiplied by 100 .

\section{Statistical analysis}

Statistical analysis of the effect of the formulation on various physicochemical properties was performed using a one-way analysis of variance and Tukey's test. The effect of formulation type and time on the antisense effect was evaluated using a repeated measures analysis of variance and Tukey's test. $P<0.05$ denoted significance in all cases.

\section{Results and Discussion}

We recently reported on the successful packaging of an antisense ODN in a MEND by the lipid hydration method (Yamada etal 2005b). The R8-MEND encapsulating ODN (ODN-MEND) would be expected to exhibit a significant antisense effect, since an R8-MEND encapsulating an siRNA expression plasmid showed a potent silencing effect in-vitro (Moriguchi etal 2005). In the siRNA experiment, we prepared three R8-MENDs, in which plasmid DNA had been condensed using three different polycations (PLL, STR-R8 and protamine) and compared the silencing effects of the R8-MENDs. The most potent effect was induced by the MEND encapsulating protamine-condensed DNA (Moriguchi et al 2005).

Therefore, in this study, we prepared three types of ODNMEND, which encapsulated pDNA encoding luciferase and an anti-luciferase ODN condensed by PLL, STR-R8 and protamine. Preparation of the R8-MEND consists of four steps (i.e., condensation of ODN or pDNA with polycations, electrostatic binding of the condensed DNA to lipid membrane, lipid coating and modification of the envelope surface with STR-R8 (Figure 1)). In this study, DNA was condensed by polycations as positively charged particles. On the other hand, the MEND showed negative zeta-potential before surface modification with R8 peptide (data not shown). These results indicate that condensed DNA particles were trapped inside the MENDs in all three preparations. We then examined the antisense effect of the ODN-MENDs by transfecting NIH3T3 cells. The R8MEND encapsulating the STR-R8-condensed ODN (ODN-MEND(STR-R8)) showed a low silencing effect $(15 \%) 8 \mathrm{~h}$ after transfection, and no silencing effect was observed at $24 \mathrm{~h}$ (Table 1). The R8-MEND encapsulating 
Table 1 Antisense effect of ODN-MEND(STR-R8), ODN-MEND(PLL) and ODN-MEND(Prot) encapsulating luciferase-pDNA and antiluciferase antisense ODN in NIH3T3 cells

\begin{tabular}{lcccc}
\hline & \multicolumn{2}{c}{ Antisense effect (\%) } & & \\
\cline { 2 - 5 } & $8 \mathrm{~h}$ & $16 \mathrm{~h}$ & $24 \mathrm{~h}$ & $48 \mathrm{~h}$ \\
\hline OND-MEND(PLL) & $0 \pm 0$ & $0 \pm 0$ & $0 \pm 0$ & $0 \pm 0$ \\
ODN-MEND(STR-R8) & $15.2 \pm 25.6$ & $13.0 \pm 22.6$ & $0 \pm 0$ & $3.7 \pm 6.5$ \\
ODN-MEND(Prot) & $71.7 \pm 9.3$ & $93.4 \pm 3.2$ & $85.7 \pm 6.6$ & $77.6 \pm 16.3$ \\
Lipofectamine2000 & $54.8 \pm 21.0$ & $46.0 \pm 22.0$ & $27.6 \pm 3.6$ & $13.4 \pm 10.7$ \\
\hline
\end{tabular}

Luciferase activity was measured at 8, 16, 24 and $48 \mathrm{~h}$ after the transfection of NIH3T3 cells with the ODN-MEND. The percentage of the antisense effect was calculated by subtracting the luciferase activity of ODN-MEND (antisense) from the control luciferase activity divided by control luciferase activity multiplied by 100 . The values are the means \pm s.d., $\mathrm{n}=3$.

PLL-condensed ODN (ODN-MEND(PLL)) did not show any silencing effect. The R8-MEND encapsulating the protamine-condensed ODN (ODN-MEND(Prot)), however, significantly inhibited luciferase activity (i.e., the silencing effect of ODN-MEND(Prot) was $90 \%$ at $16 \mathrm{~h}$ after transfection, and was maintained at $77 \%$ for periods of up to $48 \mathrm{~h}$ ). There were significant differences among the formulations, except for between ODN-MEND(PLL) and ODNMEND(STR-R8). However, no significant difference was observed in the effect of incubation time on the antisense effects. This pattern of the antisense effect among ODNMENDs was similar to those of R8-MENDs encapsulating plasmid DNA encoding siRNA (Moriguchi et al 2005), although the physicochemical characteristics of ODNs are significantly different from plasmid DNA. On the other hand, the silencing effect of LipofectAmine 2000 (LA2000), a commercially available transfection reagent, was only $55 \%$ at $8 \mathrm{~h}$ after the co-transfection of luciferasepDNA and anti-luciferase ODN, and this decreased to $13 \%$ at $48 \mathrm{~h}$ (Table 1). ODN-MEND(Prot) and LA2000 showed significant toxicity (Table 2). However, no toxicity was observed in ODN-MEND(PLL)- and ODNMEND(STRR8)-treated cells. In addition, protamine should have little toxicity, because that peptide is approved by the FDA for clinical use in the USA (Sorgi et al 1997).

Table 2 Comparison of the toxicity of ODN-MENDs with LA2000

\begin{tabular}{lc}
\hline Treatment & MTT assay values (\%) \\
\hline ODN-MEND(PLL) & $100.0 \pm 13.5$ \\
ODN-MEND(STR-R8) & $79.6 \pm 10.0$ \\
ODN-MEND(Prot) & $58.8 \pm 6.5$ \\
LA2000 & $40.3 \pm 5.3$
\end{tabular}

The toxicity of ODN-MENDs and LA2000 was evaluated by MTT assay of the cells $48 \mathrm{~h}$ after the transfection with them. Values of MTT assay were represented by percentage of absorbance of the transfected cells divided by that of non-treatment cells multiplied by 100. The ODN-MEND(Prot) and LA2000 showed significant toxicity as compared with non-treatment $(P<0.05)$. The values are the means \pm s.d., $\mathrm{n}=3$.
This therefore suggests that the antisense effect of ODNMEND(Prot) is related to its toxicity. On the other hand, LA2000 seems to have inherent toxicity by itself, because the toxicity of LA2000 was higher than that of ODNMEND(Prot), although the difference was not significant.

The cellular up-take of the MENDs is suggested to be almost the same, because all the MENDs were coated with the same lipid membrane, and there was no significant difference in their zeta-potentials (Table 3). Thus, it is suggested that uptake efficiency is not responsible for the difference in antisense effects of the MENDs. Then, we compared the transfection activity of the three MENDs, since the inhibitory effects of ODN-MENDs were expected to be influenced by transfection efficiency of pDNA. As summarized in Table 4, no significant difference was observed in the luciferase activity of the three types of MENDs in NIH3T3 cells. In our previous report, however, R8-MEND(Prot) showed a higher activity than the other MENDs in COS7 cells. This discrepancy is likely due to differences in experimental conditions, such as the cell type and amount of pDNA. Therefore, it is suggested that transfection efficiency did not affect the antisense effects of ODN-MENDs in the present experimental conditions.

We then performed a sucrose density gradient fractionation to compare the morphological characteristics, such

Table 3 Characteristics of ODN-MEND(STR-R8), ODNMEND(PLL) and ODN-MEND(Prot)

\begin{tabular}{llll}
\hline ODN-MEND & $\begin{array}{l}\text { Diameter } \\
(\mathbf{n m})\end{array}$ & $\begin{array}{l}\text { Zeta-potential } \\
(\mathbf{m V})\end{array}$ & $\begin{array}{l}\text { Encapsulation } \\
\text { efficiency (\%) }\end{array}$ \\
\hline STR-R8 & $377 \pm 7$ & $46.9 \pm 5.6$ & $91.3 \pm 1.3$ \\
PLL & $389 \pm 7$ & $39.6 \pm 5.6$ & $90.2 \pm 3.2$ \\
Protamine & $397 \pm 5$ & $40.4 \pm 9.4$ & $92.4 \pm 2.1$ \\
\hline
\end{tabular}

The encapsulation efficiency was calculated by the amount of ODN in ODN encapsulated fractions divided by the total amount of ODN multiplied by 100 . A significant difference was observed only between the diameters of STR-R8 and protamine $(P<0.05)$. The values are the means \pm s.d., $\mathrm{n}=3$. 
Table 4 Comparison of transfection activity of ODN-MENDs at various incubation periods

\begin{tabular}{llll}
\hline & \multicolumn{2}{l}{ Luciferase activity (RLU (mg protein) ${ }^{-1}$ ) } \\
\cline { 2 - 4 } & $8 \mathrm{~h}$ & $16 \mathrm{~h}$ & $24 \mathrm{~h}$ \\
\hline OND-MEND(PLL) & $4.7 \times 10^{3} \pm 3.4 \times 10^{3}$ & $1.2 \times 10^{4} \pm 1.4 \times 10^{4}$ & $2.5 \times 10^{4} \pm 9.2 \times 10^{3}$ \\
ODN-MEND(STR-R8) & $1.1 \times 10^{4} \pm 6.3 \times 10^{3}$ & $9.4 \times 10^{4} \pm 8.2 \times 10^{4}$ & $3.7 \times 10^{5} \pm 3.4 \times 10^{5}$ \\
ODN-MEND(Prot) & $4.3 \times 10^{4} \pm 3.5 \times 10^{4}$ & $9.1 \times 10^{4} \pm 6.2 \times 10^{4}$ & $4.8 \times 10^{5} \pm 4.0 \times 10^{5}$ \\
\hline
\end{tabular}

Luciferase activity was measured at 8, 16, 24 and $48 \mathrm{~h}$ after the transfection of NIH3T3 cells with the ODN-MEND. No significant difference was observed among the three types of MENDs. The values are the means \pm s.d., $\mathrm{n}=3$.

as density and ratio of ODN to lipid, among the three types of ODN-MENDs, because the difference in morphological characteristics was expected to relate to the function of the ODN-MEND. In the case of ODNMEND(STR-R8), the ODN was distributed heterogeneously in fractions no. $4(10-15 \%), 7(20-25 \%), 9(25-$ $30 \%)$ and $10(30-40 \%)$ (Figure $2 \mathrm{~A})$, indicating the structural heterogeneity of the ODN-MEND(STR-R8). On the other hand, sucrose density gradient fractionation of ODN-MEND(PLL) and ODN-MEND(Prot) showed a homogenous distribution of the MENDs (Figures 2B and 2C). Most of the ODN was detected in fractions no. $10(30-40 \%)$ and $11(40-60 \%)$ in the cases of ODNMEND(PLL) and ODN-MEND(Prot). Both ODNMENDs had a higher density and a more homogenous distribution than the ODN-MEND(STR-R8). The size and zeta-potential of the ODN-MENDs are summarized in Table 3. The diameters of all of the ODN-MENDs were around $380 \mathrm{~nm}$, and the zeta-potentials were significantly positive. The diameter of ODN-MEND(Prot) was slightly, but significantly, larger than that of ODN-MEND(STRR8). However, there was no significant difference among the zeta-potentials of any of the ODN-MENDs. In addition, the successful packaging of all the ODN-MENDs was shown by the co-existence of lipid and ODN, and the elimination of the fluorescent resonance energy transfer (FRET) between rhodamine-labelled lipid and an FITClabelled ODN with SDS (data not shown). The encapsulation efficiency of the three ODN-MENDs was over $90 \%$. Only ODN-MEND(Prot), however, showed a significant antisense effect (Table 1). This suggests that there is no relation between the physicochemical characteristics of the ODN-MENDs and their antisense effects.

Thus, the condensation state of the ODN appears to be responsible for the difference in antisense effect of the three types of ODN-MENDs, since the effects were dependent on polycations. Furthermore, these findings suggest that a relationship between the condensation state of DNA and the function of the R8-MEND exists, because the electrophoretic pattern of the plasmid DNA encapsulated in R8-MEND with protamine, which showed the highest silencing effect, was different from those prepared using PLL and STR-R8 (Moriguchi et al 2005). We then measured the diameter and zeta-potential of ODNs condensed using PLL, STR-R8 and protamine at various nitrogen/phosphate $(\mathrm{N} / \mathrm{P})$ ratios to compare the condensing state of the ODN with the three polycations (Figure 3). In the case of PLL, the diameter was less than $100 \mathrm{~nm}$ and the zeta-potential was positive (about $10-20 \mathrm{mV}$ ) above an N/P ratio of 2.4. Aggregation was observed at an $\mathrm{N} / \mathrm{P}$ ratio of 1.8 , where the zeta-potential was neutral. The condensed ODN had a diameter of about $130-170 \mathrm{~nm}$ and was negatively charged $(-20$ to $-30 \mathrm{mV}$ ) below the neutral point. Similarly, in the case of STR-R8, aggregation was also observed at an $\mathrm{N} / \mathrm{P}$ ratio of 1.2, and the diameter and zeta-potential patterns were similar to samples prepared using PLL. On the other hand, in the case of protamine, no aggregation was observed, and the diameters were in the range 100 $200 \mathrm{~nm}$, although the zeta-potential pattern was similar to the others. A significant difference was observed between the diameters of ODN particles condensed by PLL and protamine or STR-R8 and protamine at N/ $\mathrm{P}=2.4$. On the other hand, no significant difference was observed among zeta-potentials.

PLL and STR-R8 are homopolymers of positively charged amino acids, while protamine (amino-acid sequence: PRRRRSSSRPVRRRRRPRVSRRRRRRGGRRRR) consists of 4 oligo-arginine regions separated by several neutral amino acids. The size of the protamine-condensed particles was larger than that of the PLL- and STR-R8condensed particles as shown in Figure 3A. In addition, we previously reported that the protamine-condensed pDNA core of the MEND was more flexible than PLLand STR-R8-condensed cores (Moriguchi et al 2005). These observations suggest that a protamine-condensed DNA core is more easily decondensed than PLL and STR$\mathrm{R} 8$, because the non-charged amino acids in the protamine sequence could prevent tight interactions between the DNA and oligo-arginine regions. Another possibility is that the morphological characteristics, such as particle size and zeta-potential, at different $\mathrm{N} / \mathrm{P}$ ratios, relate to the difference in decondensability of condensed DNA core. In fact, the size and zeta-potential of the core particle condensed with protamine $(\mathrm{N} / \mathrm{P}=2.2)$ were larger than those with PLL $(\mathrm{N} / \mathrm{P}=2.4)$ and STR-R8 $(\mathrm{N} / \mathrm{P}=2.9)$ (Figure 3). However, the decondensability of pDNA in all MENDs appeared to be almost the same under the present experimental conditions, because there was no significant difference among the gene expression of all MENDs (Table 4). This therefore suggests that the decondensation of ODN is different in the three types of 


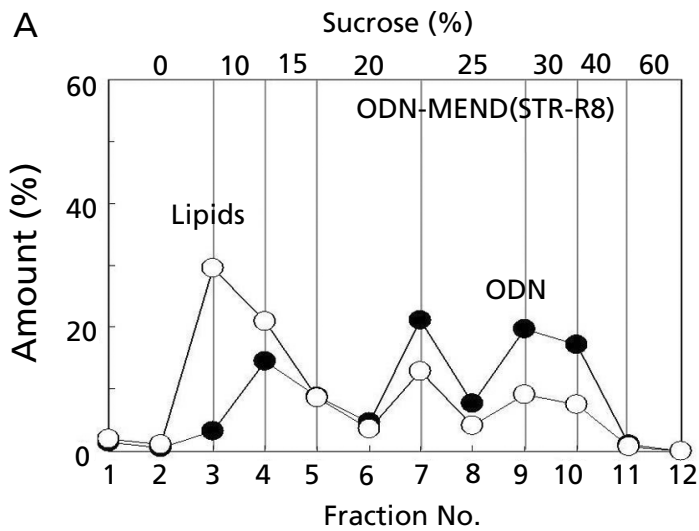

B

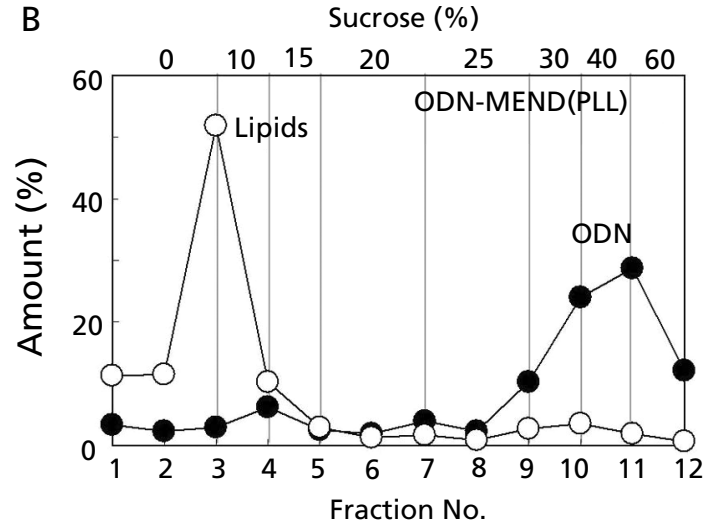

C



Figure 2 Distribution of ODN and lipids after discontinuous sucrose density gradient ultracentrifugation of the ODN-MEND. A. ODN-MEND(STR-R8). B. ODN-MEND(PLL). C. ODNMEND(Prot). Amounts of ODN (•) and lipids (O) were estimated by measuring the fluorescence intensity of FITC-labelled ODN and rhodamine-labelled lipid in each fraction, respectively, $\mathrm{n}=2$.

MENDs, since the antisense effect was dependent on the polycation used (i.e. ODN-MEND(Prot) showed the most potent antisense effect (Table 1)). This discrepancy between pDNA and ODN should be due to the unique characteristics of ODN, such as its very short length and single-stranded structure. Thus, the protamine-condensed DNA is probably delivered to the cytosol and ODN is released efficiently from the protamine-condensed particle.
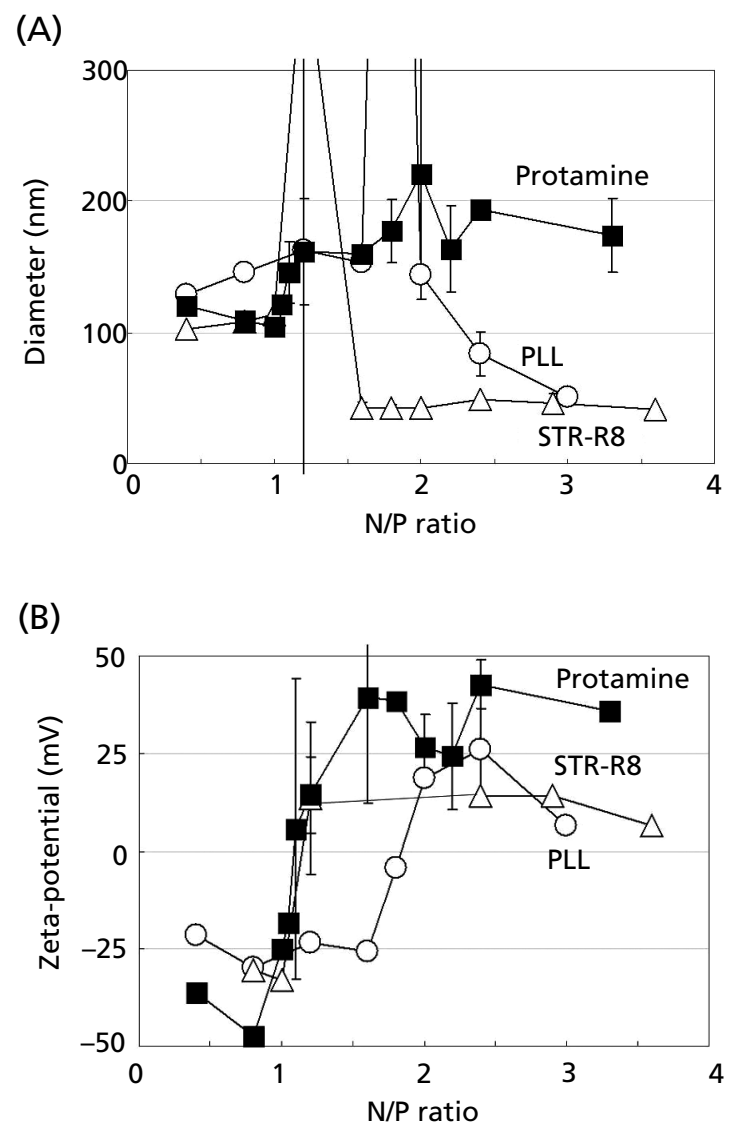

Figure 3 Relationship between N/P ratio and the diameter or zetapotential of the ODN condensed with polycations. An ODN solution was added to a polycation solution, such as STR-R8 $(\triangle), \operatorname{PLL}(\bigcirc)$ or protamine $(\boldsymbol{\square})$, under vortexing at room temperature and the diameter (A) and zeta-potential (B) were then measured. At $\mathrm{N} / \mathrm{P}=2.4$, a significant difference was observed between diameters of ODN particles condensed by PLL and protamine or STR-R8 and protamine, $\mathrm{n}=3$.

On the other hand, it has previously been reported that the protamine-condensed plasmid DNA of R8-MEND could be decondensed efficiently after delivery to the nucleus (Moriguchi et al 2005). Actually, we recently demonstrated by means of a nuclear microinjection technique that the intranuclear transcription efficiency of protamine/DNA complex was significantly higher than that of the PLL/ DNA complex (Masuda et al 2005). In addition, it is possible that the R8 peptide assists not only the internalization of MENDs into cells but also the nuclear transfer of pDNA. This suggests that R8-MENDs are able to deliver encapsulated DNA to the cytosol as well as the nucleus, and that protamine plays a role as an efficient decondenser of the condensed DNA core of the R8-MEND, not only in the nucleus but also in the cytosol.

\section{Conclusions}

Three types of R8-MENDs co-encapsulating luciferaseencoding pDNA and anti-luciferase ODN condensed by 
three polycations, STR-R8, PLL and protamine, were prepared, and the antisense effects of the ODN-MENDs on luciferase activity were determined.

The ODN-MEND packaged using protamine as a condenser showed a $90 \%$ antisense effect $16 \mathrm{~h}$ after the transfection, and a persistent antisense effect of over $75 \%$ up to $48 \mathrm{~h}$. On the other hand, the silencing effect of LipofectAmine 2000 was only $55 \% 8 \mathrm{~h}$ after the co-transfection, and this decreased to $13 \%$ at $48 \mathrm{~h}$. The ODNMENDs prepared using PLL and STR-R8 as condensers, however, did not show any significant antisense effect. The ODN-MENDs packaged with PLL or protamine were high density and homogeneous as demonstrated by sucrose density gradient fractionation, while the ODNMEND packaged with STR-R8 was heterogeneous. In addition, the diameters and zeta-potentials of the three ODN-MENDs were similar.

Although there was no specific relation between the physicochemical characteristics of the ODN-MENDs and their antisense effect, the pattern of the antisense effect among the ODN-MENDs was similar to those of the silencing effect of the R8-MEND encapsulating plasmid DNA encoding siRNA. These results suggest that the R8MENDs are able to deliver encapsulated DNA to the cytosol as well as to the nucleus, and that protamine can also function as an efficient decondenser not only in the nucleus but also in the cytosol. Collectively, ODN-MEND(Prot) with a significant and prolonged antisense effect was successfully developed. This type of ODN-MEND promises to serve as a useful tool in gene silencing research.

\section{References}

Brewer, L. R., Corzett, M., Balhorn, R. (1999) Protamineinduced condensation and decondensation of the same DNA molecule. Science 286: 120-123

Futaki, S., Ohashi, W., Suzuki, T., Niwa, M., Tanaka, S., Ueda, K., Harashima H., Sugiura, Y. (2001) Stearylated argininerich peptides: a new class of transfection system. Bioconjug. Chem. 12: 1005-1011

Gokhale, P. C., Soldatenkov, V., Wang, F. H., Rahman, A., Dritschilo, A., Kasid, U. (1997) Antisense raf oligodeoxyribonucleotide is protected by liposomal encapsulation and inhibits Raf-1 protein expression in vitro and in vivo: implication for gene therapy of radioresistant cancer. Gene Ther. 4: 1289-1299

Kakudo, T., Chaki, S., Futaki, S., Nakase, K. I., Akaji, K., Kawakami, T., Maruyama, K., Kamiya, H., Harashima, H. (2004) Transferrin-modified liposomes equipped with a $\mathrm{pH}-$ sensitive fusogenic peptide: an artificial viral-like delivery system. Biochemistry 18: 5618-5628

Khalil, I. A., Futaki, S., Niwa, M., Baba, Y., Kaji, N., Kamiya, H., Harashima, H. (2004) Mechanism of improved gene transfer by the N-terminal stearylation of octaarginine: enhanced cellular association by hydrophobic core formation. Gene Ther. 11: 636-644

Kogure, K., Moriguchi, R., Sasaki, K., Ueno, M., Futaki, S., Harashima, H. (2004) Development of a non-viral multifunctional envelope-type nano device by a novel lipid film hydration method. J. Control. Release 98: 317-323
Masuda, T., Akita, H., Harashima, H. (2005) Evaluation of nuclear transfer and transcription of plasmid DNA condensed with protamine by microinjection: the use of a nuclear transfer score. FEBS Lett. 579: 2143-2148

Miyake, H., Hara, I., Kamidono, S., Gleave, M. (2001) Novel therapeutic strategy for advanced prostate cancer using antisense oligodeoxynucleotides targeting anti-apoptotic genes upregulated after androgen withdrawal to delay androgenindependent progression and enhance chemosensitivity. Int. J. Urol. 8: 337-349

Moriguchi, R., Kogure, K., Akita, H., Futaki, S., Miyagishi, M., Taira, K., Harashima, H. (2005) A multifunctional envelopetype nano device for novel gene delivery of siRNA plasmids. Int. J. Pharm. 301: 277-285

Nakase, I., Niwa, M., Takeuchi, T., Sonomura, K., Kawabata, N., Koike, Y., Takehashi, M., Tanaka, S., Ueda, K., Simpson, J. C., Jones, A. T., Sugiura, Y., Futaki, S. (2004) Cellular uptake of arginine-rich peptides: roles for macropinocytosis and actin rearrangement. Mol. Ther. 10: 1011-1022

Phillips, M. I. (2001) Gene therapy for hypertension. Hypertension 38: 543-548

Sasaki, K., Kogure, K., Chaki, S., Kihira, Y., Ueno, M., Harashima, H. (2005) Construction of multifunctional envelope-type nano device by a SUV*-fusion method. Int. J. Pharm. 296: $142-150$

Scherer, L. J., Rossi, J. J. (2003) Approaches for the sequencespecific knockdown of mRNA. Nat. Biotechnol. 21: 14571465

Semple, S. C., Klimuk, S. K., Harasym, T. O., Dos Santos, N., Ansell, S. M., Wong, K. F., Maurer, N., Stark, H., Cullis, P. R., Hope, M. J., Scherrer, P. (2001) Efficient encapsulation of antisense oligonucleotides in lipid vesicles using ionizable aminolipids: formation of novel small multilamellar vesicle structures. Biochim. Biophys. Acta 1510: $152-166$

Shi, F., Hoekstra, D. (2004) Effective intracellular delivery of oligonucleotides in order to make sense of antisense. $J$. Control. Release 97: 189-209

Sorgi, F. L., Bhattacharya, S., Huang, L. (1997) Protamine sulfate enhances lipid-mediated gene transfer. Gene Ther. 4: 961-968

Stephenson, M. L., Zamecnik, P. C. (1978) Inhibition of Rous sarcoma viral RNA translation by a specific oligodeoxyribonucleotide. Proc. Natl Acad. Sci. USA 75: 285-288

Xu, Y., Zhang, H. Y., Thormeyer, D., Larsson, O., Du, Q., Elmen, J., Wahlestedt, C., Liang, Z. (2003) Effective small interfering RNAs and phosphorothioate antisense DNAs have different preferences for target sites in the luciferase mRNAs. Biochem. Biophys. Res. Commun. 306: 712-717

Yamada, Y., Shinohara, Y., Kakudo, T., Chaki, S., Futaki, S., Kamiya, H., Harashima, H. (2005a) Mitochondrial delivery of mastoparan with transferrin liposomes equipped with a $\mathrm{pH}$ sensitive fusogenic peptide for selective cancer therapy. Int. $J$. Pharm. 299: 34-40

Yamada, Y., Kogure, K., Nakamura, Y., Inoue, K., Akita, H., Nagatsugi, F., Sasaki, S., Suhara, T., Harashima, H. (2005b) Development of efficient packaging method of oligodeoxynucleotides by a condensed nano particle in lipid envelope structure. Biol. Pharm. Bull. 28: 1939-1942

Zamecnik, P. C., Stephenson, M. L. (1978) Inhibition of Rous sarcoma virus replication and cell transformation by a specific oligonucleotide. Proc. Natl Acad. Sci. USA 75: 280284 
